\title{
Minimally Invasive Open Surgical Approach and Outcomes for Carpal Tunnel Syndrome
}

\author{
(1) İsmail Yüce, ${ }^{1}$ (D) Okan Kahyaoğlu, ${ }^{2}$ (1) Halit Çavuşoğlu, ${ }^{1}$ ㄴ) Yunus Aydın² \\ 'Vocational School of Health Services, Acibadem Mehmet Ali Aydinlar University, Istanbul, Turkey \\ ${ }^{2}$ Acibadem Healthcare Group, Fulya Hospital, Neurosurgery, Istanbul, Turkey
}

\begin{abstract}
Objectives: The most common peripheral neuropathy is carpal tunnel syndrome. The present study aims to describe our minimally invasive open surgical approach for carpal tunnel syndrome and evaluate surgical outcomes.

Methods: We included 217 patients who were operated in our clinic for carpal tunnel syndrome by minimally invasive open surgical approach. Visual Analogue Scale and Functional Outcome Scale scores were obtained preoperative, postoperative at one month and three months to determine surgical outcomes.

Results: The mean age of the patients was $55.4 \pm 12.8$ years (32 to 69), 175 (80.6\%) were women and 42 (19.4\%) were men. The assessment of carpal tunnel syndrome's etiology showed that 189 (\%87.1\%) of the cases were idiopathic, 19 (8.8\%) had hypothyroidism, 5 (2.3\%) had rheumatoid arthritis and 4 (1.8\%) were due to pregnancy. The average improvement of VAS between preoperatively and late postoperatively was $5.41 \pm 1.05$. The average improvement FOS was $17.44 \pm 3.06$. They were statistically significant. Conclusion: The minimally invasive open surgical approach for carpal tunnel syndrome (an average of $1 \mathrm{~cm}$ skin incision) is performed with local anesthesia and successful surgical outcomes are achieved.

Keywords: Carpal tunnel syndrome; minimally invasive open surgical approach; transverse carpal ligament.

Please cite this article as "Yüce I, Kahyaoğlu O, Çavuşoğlu H, Aydın Y. Minimally Invasive Open Surgical Approach and Outcomes for Carpal Tunnel Syndrome. Med Bull Sisli Etfal Hosp 2019;53(3):247-251".
\end{abstract}

$\mathrm{T}$ he most frequently encountered of the peripheral neuropathies is the carpal tunnel syndrome (CTS). ${ }^{[1,2]}$ Main symptoms include pain, weakness, and sensation disorders. The incidence is $1 \%$. CTS is threefold higher in women. ${ }^{[3]}$ Although many pathological variations exist in etiology (such as rheumatoid arthritis, pregnancy, hypothyroidism), CTS is mostly idiopathic. ${ }^{[4,5]}$ The common symptom is severe paresthesia, especially during the night. The most common findings include positive Tinnel and Phalen tests and sensory and/or motor latency prolongation during an electromyography (EMG) workup. For the surgical treatment, an incision of the transverse carpal ligament (TCL) has proven to be low risk and effective surgical treatment method. This approach was first performed by Phalen. [6] The most frequent complication is the development of hypertrophic and painful scar tissue. ${ }^{[7]}$ Therefore, surgeons perform the transverse ligament incision with certain modifications and try to decrease the common complication rate. Considering the basic surgery principles, the proper approach should involve shortening the incision and minimizing the tissue damage. The present study aims to describe our minimally invasive open surgical approach, which was described by the senior author (Y.A.) and to evaluate surgical outcomes.

Address for correspondence: İsmail Yüce, MD. Acıbadem Mehmet Ali Aydinlar Universitesi Saglik Hizmetleri Meslek Yüksekokulu, Istanbul, Turkey Phone: +90 5053760182 E-mail: dr.ismailyuce@gmail.com

Submitted Date: January 29, 2019 Accepted Date: May 17, 20179 Available Online Date: August 26, 2019

${ }^{\circ}$ Copyright 2019 by The Medical Bulletin of Sisli Etfal Hospital - Available online at www.sislietfaltip.org

OPEN ACCESS This is an open access article under the CC BY-NC license (http://creativecommons.org/licenses/by-nc/4.0/). 


\section{Methods}

217 patients, who were operated in our clinic due to a carpal tunnel syndrome were included in our study. The retrospective evaluation of the patients included an assessment of age, sex, etiology, EMG findings, and side of the surgery. To quantify the surgical outcomes, the Visual Analogue Scale (VAS) and Functional Outcome Scale (FOS) scores were obtained preoperative, postoperative at one month and three months. Surgical procedures of patients who were diagnosed with bilateral CTS were performed two weeks after the first surgery.

\section{Statistical Analysis}

Microsoft Excel-2013 and SPSS 21 (Statistical Package for Social Sciences) were used for the statistical comparison of the results. The statistical analysis was performed with T-tests (Cl: Confidence Interval 95\%).

\section{Surgical Procedure}

The surgical instruments must be appropriate for a short incision (Fig. 1). A skin incision is made reaching $1 \mathrm{~cm}$ (the rate of surgical procedures with shorter incisions is $42.8 \%$ ) distal from the starting point which is the intersection between the TCL and the longitudinal line drawn between the palmar side of the third and fourth fingers, towards the wrist (Fig. 2). The TCL is reached through the elimination of subcutaneous fatty tissue and palmar aponeurosis (while paying close attention to not severing superficial palmar

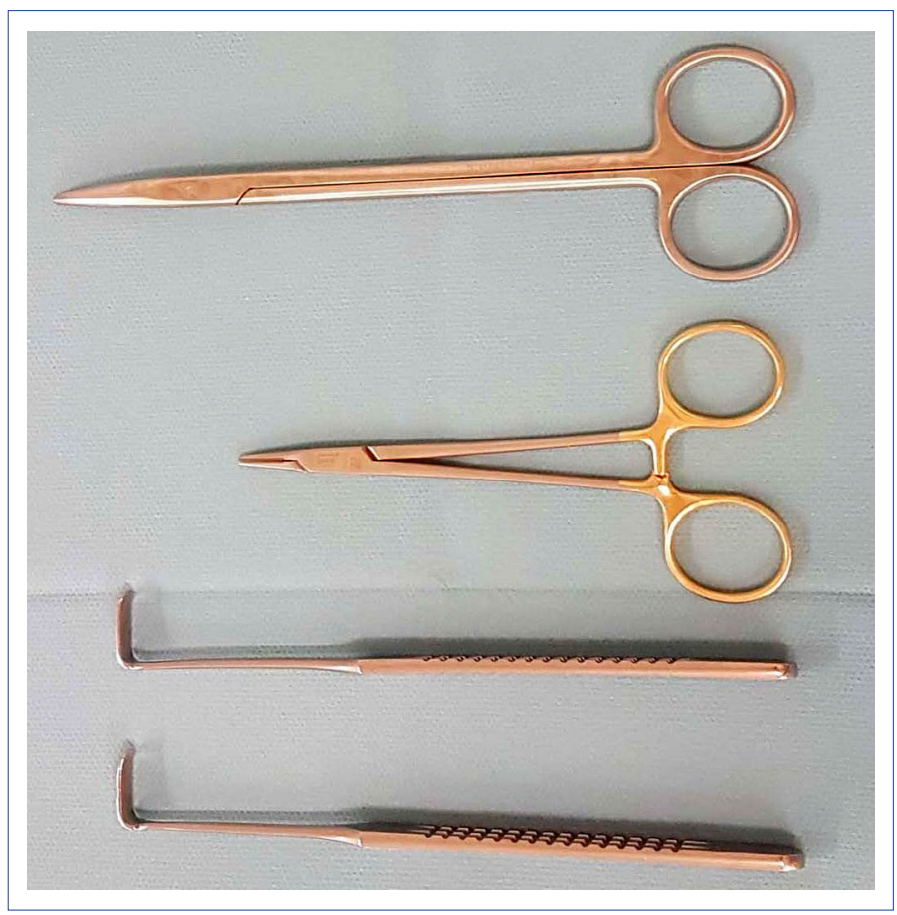

Figure 1. Surgical instruments. arch and motor arches of the median nerve with their variable locations). An incision is then made to the ligament with a scalpel (Fig. 3). Next, the median nerve surface of the ligament is traced distally with the tip of blunt scissors and the TCL is cut step-by-step towards proximal by using the space between the nerve and the ligament (Fig. 4). It is checked over the skin, whether the tip of the scissors has reached the proximal end of the ligament (Fig. 5). After closing the scissors, it is steered towards subcutaneous tissues and pulled in the distal direction. At this

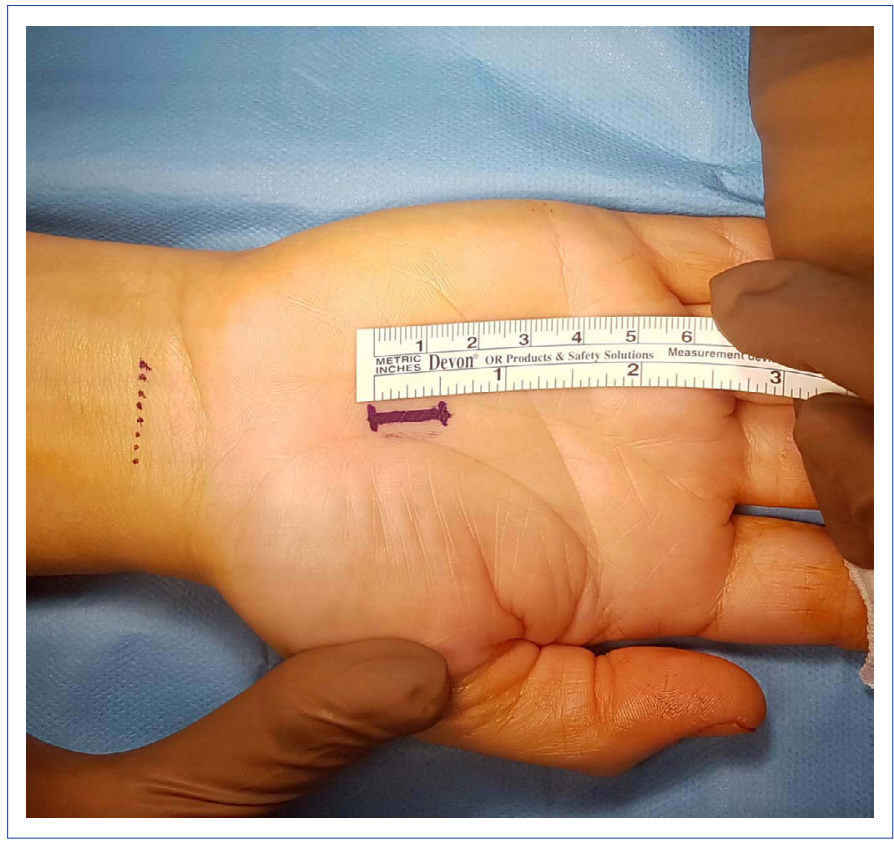

Figure 2. Location of skin incision.

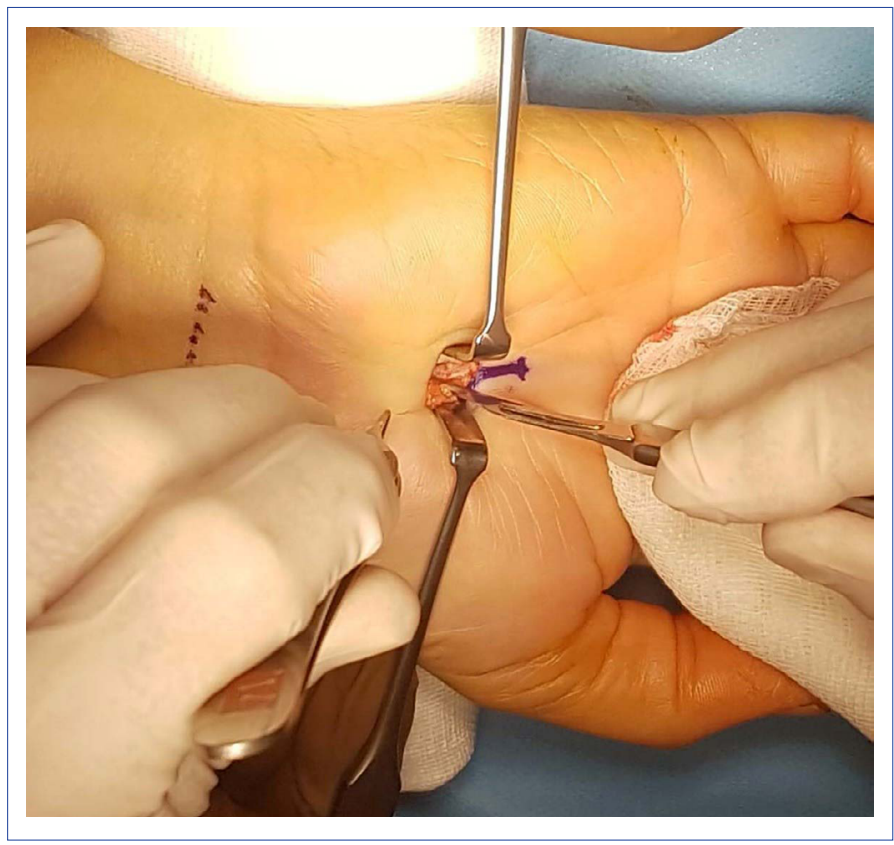

Figure 3. Reach to the transverse carpal ligament. 


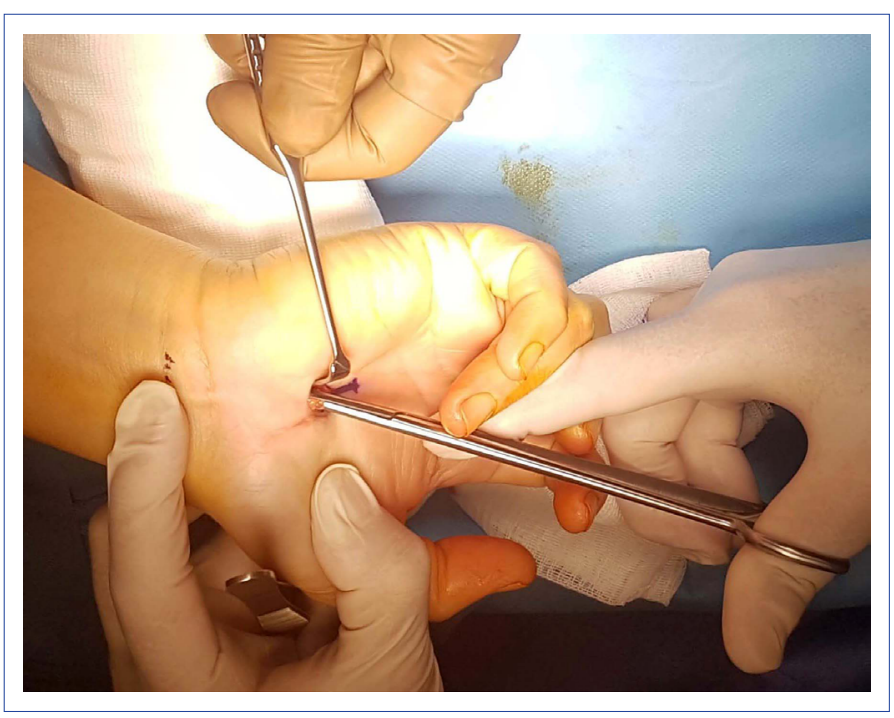

Figure 4. Cutting the transverse carpal ligament.

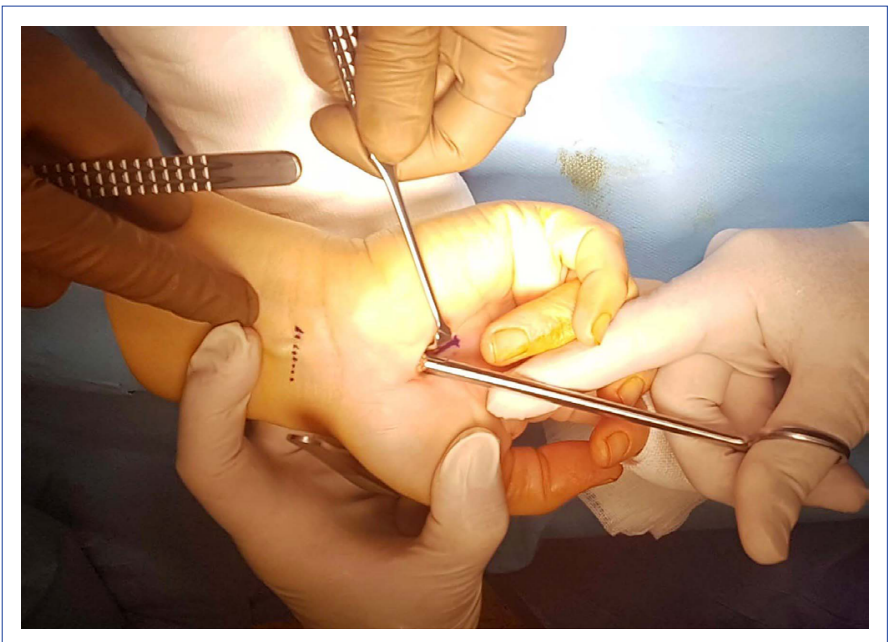

Figure 5. Checking the proximal end of the ligament.

stage, the surgeon confirms that there are no uncut areas on the TCL. Then, the median nerve distal from the incision is checked, if it is unconstrained and the remaining ligament portion is incised, in case there is any residual (Fig. 6). Following the hemostasis (usage of cautery must be avoided), the skin is closed subcutaneously with $3 / 0$ vicryl. Two weeks after the surgery, the patients are taught the proper exercises.

\section{Results}

This approach was performed altogether 231 surgery in 217 patients ( 14 cases involved bilateral CTS) between the years 2008-2017. The mean age of the patients was $55.4 \pm 12.8$ years (32 to 69), 175 (80.6\%) were women and 42 (19.4\%) were men. The assessment of CTS etiology showed that $189(\% 87.1 \%)$ of the cases were idiopathic, $19(8.8 \%)$ had

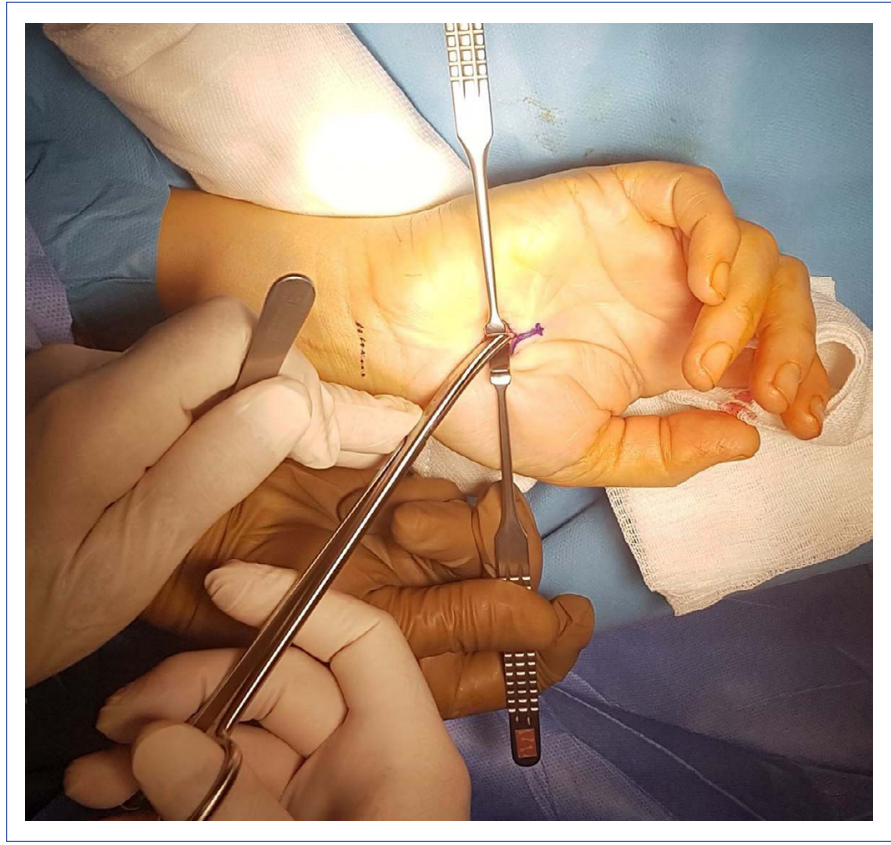

Figure 6. Checking the distal part of the transverse carpal ligament.

hypothyroidism, 5 (2.3\%) had rheumatoid arthritis and 4 (1.8\%) were due to pregnancy. The average during of symptoms was $13.3 \pm 5.6$ months. Paresthesia was determined in all of the cases. Other symptoms included 138 (63.5\%) paresthesia, 106 (48.9\%) weakness, $184(84.8 \%)$ pain and numbness during night. The Tinnel test was positive in 192 (88.4\%) and the Phalen test was 164 (75.6\%) positive. The comparison of the EMG findings of the patients showed results; 20 (9.3\%) moderate, 168 (77.4\%) moderate-severe, and $29(13.3 \%)$ severe. Thenar atrophy was observed in 19 (8.7\%) patients. $92(\% 42.2)$ of the patients were operated right, 111 were (51.1\%) left, and 14 (6.5\%) were operated double-sided (Table 1).

The mean VAS scores of the patients were determined as $5.47 \pm 1.05$ preoperative, $0.84 \pm 0.67$ postoperative (early), and $0.51 \pm 0.21$ postoperative (late). The average improvement of VAS between preoperatively and late postoperatively was $5.41 \pm 1.05$. This difference was statistically significant $(\mathrm{p}=0.001)$. The assessed FOS showed; 25.48 \pm 3.10 preoperative, $8.18 \pm 0.69$ postoperative (early), and $8.04 \pm 0.30$ postoperative (late). The average improvement of FOS was $17.44 \pm 3.06$, and it was statistically significant $(p=0.001)$ (Table 2).

Any nerve injury or increase of symptoms after surgery was not observed. Three patients with severe-level EMG findings and thenar atrophy expressed that their symptom decrease was not sufficient, despite the improvement of their EMG results (they had been informed during the diagnosis stage). Accordingly, the sufficient outcome was $98.6 \%$ (214 patients). There were not any recurrence surgeries. The re- 
Table 1. Demography of the patients

\begin{tabular}{lcc}
\hline Mean age (years) & \multicolumn{2}{c}{$55.4 \pm 12.8$} \\
\hline Parameters & $\mathbf{n}$ & $\%$ \\
\hline Gender & 175 & \\
$\quad$ Female & 42 & 80.6 \\
$\quad$ Male & & 19.4 \\
Etiology & 189 & \\
$\quad$ Idiopathic & 19 & 87.1 \\
$\quad$ Hypothyroidism & 5 & 8.8 \\
$\quad$ Rheumatoid arthritis & 4 & 2.3 \\
$\quad$ Pregnancy & & 1.8 \\
EMG & 20 & 9.3 \\
$\quad$ Moderate & 168 & 77.4 \\
$\quad$ Moderate-Severe & 29 & 13.3 \\
$\quad$ Severe & & \\
Side & 92 & 42.4 \\
$\quad$ Right & 111 & 51.1 \\
Left & 14 & 6.5 \\
$\quad$ Bilateral & & \\
\hline
\end{tabular}

Table 2. VAS and FOS Scores

\begin{tabular}{lcc}
\hline VAS & Average & p \\
\hline Preoperative & $5.47 \pm 1.05$ & \\
Postoperative (early) & $0.84 \pm 0.67$ & \\
Postoperative (late) Improvement & $0.51 \pm 0.21$ & \\
(preoperative-late) & $5.41 \pm 1.05$ & 0.001 \\
FOS & & \\
Preoperative & $25.48 \pm 3.10$ & \\
Postoperative (early) & $8.18 \pm 0.69$ & \\
Postoperative (late) & $8.04 \pm 0.30$ & \\
Improvement (preoperative-late) & $17.44 \pm 3.06$ & 0.001 \\
\hline
\end{tabular}

covery of wound incision was detected to be longer than 10 days in five of patients. There was no additional treatment for them. Superficial wound infection in two cases was treated with anti-biotherapy.

\section{Discussion}

The objective of the surgical treatment for CTS, which is the most surgically intervened of the peripheral neuropathies, is the decompressing of the median nerve by incising the TCL. Open techniques and endoscopic methods are applied. ${ }^{[8,9]}$ In all of these methods, the decompression of the median nerve is ensured through the incision of the TCL and the procedure success is affected by postoperative scar tissue forming. Limitation of movement, pain and recurring compression due to scar tissue are the main reasons for surgical failure. ${ }^{[10,11]}$ While a long incision in an open surgical method results in more scar tissue formation and therefore may have a poor impact on surgical success, inadequate loosening is determined as a possible complication of the endoscopic technique. ${ }^{[12,13]}$

During the surgery, the surgeon must pay attention to possible variations of the anatomical structures surrounding the TCL (e.g. muscle and ligament, palmar cutaneous and the motor branch of the median nerve). ${ }^{[14]}$

Nerve injury-related complications are encountered less in open method compared to the endoscopic method. ${ }^{[15,}$ ${ }^{16]}$ Also, the cost of the instruments required for the endoscopic method is higher. ${ }^{[17]}$ Our approach includes a $1 \mathrm{~cm}$ skin incision (smaller incisions are possible depending on the surgical experience). Additionally, we did not observe intense scar tissue formation in any of our patients. A skin incision of $2 \mathrm{~cm}$ is defined for the mini-open method and better results have been reported compared to the endoscopic method. ${ }^{[18,19]}$

Assessment of VAS and FOS scores is common for the follow-up of the patients. EMG findings have been reported to be non-effective for the postoperative follow-ups. ${ }^{[20]}$ Studies have compared the endoscopic method and open method and revealed the primary effect of scar tissue.

In the literature, a recurrence rate of $0.5-10 \%$ has been defined for CTS surgery. ${ }^{[21,22]}$ We did not encounter any recurrence surgeries in the cases we are presenting. The average surgical time was reported 18.2 minutes for the double tunnels technique of CTS in the literature. ${ }^{[23]}$ We attribute the success of the surgical treatments and lack of complications in our cases to the incisions being much shorter compared to other methods, which resulted in less scar tissue forming. Average surgical duration of seven minutes and ability of local anesthesia usage are additional features proving the superiority of our approach.

\section{Conclusion}

The objective of the surgical treatment for CTS is the incision of the TCL, which is ensured with all methods. The good surgical outcomes depend on keeping the skin incision short and minimizing the scar tissue formation. With our "minimally invasive open surgical approach," involving an average skin incision of $1 \mathrm{~cm}$ and the ability to perform under local anesthesia (for shorter incisions), successful surgical outcomes are achieved.

\section{Disclosures}

Ethics Committee Approval: The present study is a retrospective study, and all authors waived the need for local ethics committee approval for this study.

Peer-review: Externally peer-reviewed. 
Conflict of Interest: The authors report no conflict of interest concerning the materials or methods used in this study or the findings specified in this study.

Authorship Contributions: Concept - I.Y., O.K., H.C., Y.A.; Design - I.Y., H.C., Y.A.; Supervision - H.C., Y.A.; Materials - I.Y., O.K., H.C., Y.A.; Data collection \&/or processing - I. Y., H.C., O.K., Y.A.; Analysis and/or interpretation - I. Y., H.C., Y.A.; Literature search - I. Y., H.C., Y.A.; Writing - I.Y., H.C., Y.A.; Critical review - H.C., Y.A.

\section{References}

1. Heyman VB. Electrophysiological testing. In: Gelberman RH, editor. Operative nerve repair and reconstruction. 2nd ed. Philadelphia: J.B. Lippincott; 1991. p. 170-81.

2. Szabo RM. Entrapment and compression neuropathies. In: Green DP, Hotchkiss RN and Pederson WC, editors. Green's operative hand surgery. 4th ed. Philadelphia: Churchill Livingstone; 1999. p. 1404-47.

3. D'Arcy CA, McGee S. The rational clinical examination. Does this patient have carpal tunnel syndrome? JAMA 2000;283:3110-7.

4. Kerr CD, Gittins ME, Sybert DR. Endoscopic versus open carpal tunnel release: clinical results. Arthroscopy 1994;10:266-9.

5. Phalen GS. Reflections on 21 years' experience with the carpaltunnel syndrome. JAMA. 1970 25;212:1365-7. [CrossRef]

6. Jacobsen $M B$, Rahme $H$. A prospective, randomized study with an independent observer comparing open carpal tunnel release with endoscopic carpal tunnel release. J Hand Surg $\mathrm{Br}$ 1996;21:202-4. [CrossRef]

7. Bromley GS. Minimal-incision open carpal tunnel decompression. J Hand Surg Am 1994:119-20. [CrossRef]

8. Serra JM, Benito JR, Monner J. Carpal tunnel release with short incision. Plast Reconstr Surg. 1997;99:129-35. [CrossRef]

9. Kluge W, Simpson RG, Nicol AC. Late complications after open carpal tunnel decompression. J Hand Surg Br 1996; :205-7.

10. MacDonald RI, Lichtman DM, Hanlon JJ, Wilson JN. Complications of surgical release for carpal tunnel syndrome. J Hand Surg Am
1978;3:70-6. [CrossRef]

11. Chow JC. Endoscopic release of the carpal ligament for carpal tunnel syndrome: 22-month clinical result. Arthroscopy 1990;6:28896. [CrossRef]

12. Cobb TK, Amadio PC. Reoperation for carpal tunnel syndrome. Hand Clin 1996;313-23.

13. Lindley SG, Kleinert JM. Prevalence of anatomic variations encountered in elective carpal tunnel release. J Hand Surg Am 2003;849-55. [CrossRef]

14. Lee WP, Strickland JW. Safe carpal tunnel release via a limited palmar incision. Plast Reconstr Surg 1998;101:418-24. [CrossRef]

15. Yercan HS, Özalp T, Çoşkunol E, Özdemir O. Chow tekniği ile endoskopik karpal tünel gevşetilmesi orta dönem sonuçları. Eklem Hastalik Cerrahisi 2004: 15:1-6.

16. Lee $H$, Jackson TA. Carpal tunnel release through a limited skin incision under direct visualization using a new instrument, the carposcope. Plast Reconstr Surg 1996;98:313-9. [CrossRef]

17. Tetik C, Erol B: Karpal tünel sendromunun cerrahi tedavisinde uygulanan alternatif metodların karşılaştırılması. Eklem Hastalik Cerrahisi 2002; 13: 5-9

18. Wong KC, Hung LK, Ho PC, Wong JM. Carpal tunnel release. A prospective, randomised study of endoscopic versus limitedopen methods. J Bone Joint Surg Br 2003 ;85:863-8. [CrossRef]

19. Akman S, Ertürer E, Celik M, Aksoy B, Gür B, Oztürk I. [The results of open surgical release in carpal tunnel syndrome and evaluation of follow-up criteria]. Acta Orthop Traumatol Turc 2002;36:25964.

20. Chow JC, Hantes ME. Endoscopic carpal tunnel release: thirteen years' experience with the Chow technique. J Hand Surg Am 2002;27:1011-8. [CrossRef]

21. Kern BC, Brock M, Rudolph KH, Logemann $\mathrm{H}$. The recurrent carpal tunnel syndrome. Zentralbl Neurochir 1993;54:80-3.

22. Vanni D, Sirabella FS, Galzio R, Salini V, Magliani V. The double tunnels technique:an alternative minimally invasive approach for carpaltunnel syndrome. J Neurosurg 2015;123:1230-7. [CrossRef] 